\title{
Author Correction: Preparation of Lauroyl Grafted Alginate- Psyllium Husk Gel Composite Film with Enhanced Physicochemical, Mechanical and Antimicrobial Properties
}

\section{Clara Fernandes, Pratap Chandra Acharya 1 \& Shikha Bhatt}

Correction to: Scientific Reports https://doi.org/10.1038/s41598-018-35632-9, published online 21 November 2018

In the original version of this Article, Clara Fernandes was omitted as a corresponding author. Correspondence and request for materials should also be addressed to clara_fern@yahoo.co.in. This error has now been corrected in the HTML and PDF versions of the Article, and in the accompanying Supplementary Information file.

(c) (i) Open Access This article is licensed under a Creative Commons Attribution 4.0 International License, which permits use, sharing, adaptation, distribution and reproduction in any medium or format, as long as you give appropriate credit to the original author(s) and the source, provide a link to the Creative Commons license, and indicate if changes were made. The images or other third party material in this article are included in the article's Creative Commons license, unless indicated otherwise in a credit line to the material. If material is not included in the article's Creative Commons license and your intended use is not permitted by statutory regulation or exceeds the permitted use, you will need to obtain permission directly from the copyright holder. To view a copy of this license, visit http://creativecommons.org/licenses/by/4.0/.

(c) The Author(s) 2019 